\title{
Analysis of the molecular networks involved in primary cilium formation
}

\author{
R Bonavita ${ }^{1,2^{*}}$, A Luini $^{2}$, A Luini $^{1}$, A Colanzi $^{1}$ \\ From First International Cilia in Development and Disease Scientific Conference (2012) \\ London, UK. 16-18 May 2012
}

To identify functional interactions among some important ciliopathy genes, we carried out searches related to genes representative of important ciliopathies, such as BardetBiedl syndrome (BBS), nephronophthisis, and oro-facialdigital syndrome type 1 . We built a functional interaction network for the identification of conserved components that might regulate ciliary trafficking, and thus provide insight into the mechanisms of polycystic kidney disease. By mining the published protein-protein interaction data, we identified an interesting association between the exocyst complex (involved in targeting of post-Golgi vesicles to the plasma membrane), the BBSome (a multisubunit protein complex involved in the transport of cargo to the cilium), centriolar satellites, the centrosome and the Golgi complex. In addition, this analysis led us to the identification of a new centrosomal protein of previously undefined function involved in cilium formation. We are now investigating the molecular function of this protein, as it interacts physically and functionally with OFD1, a gene associated with ciliopathies.

\section{Author details}

${ }^{1}$ Istituto di Biochimica delle Proteine, Italian National Research Council (CNR), Italy. ${ }^{2}$ Telethon Institute of Genetics and Medicine (TIGEM), Italy.

Published: 16 November 2012

doi:10.1186/2046-2530-1-S1-P15

Cite this article as: Bonavita et al:: Analysis of the molecular networks

involved in primary cilium formation. Cilia 2012 1(Suppl 1):P15.

\footnotetext{
* Correspondence: bonavita@tigem.it

${ }^{1}$ Istituto di Biochimica delle Proteine, Italian National Research Council (CNR), Italy

Full list of author information is available at the end of the article
}

Submit your next manuscript to BioMed Central and take full advantage of:

- Convenient online submission

- Thorough peer review

- No space constraints or color figure charges

- Immediate publication on acceptance

- Inclusion in PubMed, CAS, Scopus and Google Scholar

- Research which is freely available for redistribution

\section{() Biomed Central}

